\title{
Kesehatan Tenggorok pada Siswa di Sekolah Dasar Negeri 11 Manado
}

\author{
Novita Solossa, ${ }^{1}$ Steward K. Mengko, ${ }^{2}$ Augustien Y. Tamus ${ }^{2}$
}

\author{
${ }^{1}$ Program Studi Pendidikan Dokter Fakultas Kedokteran Universitas Sam Ratulangi, \\ Manado, Indonesia \\ ${ }^{2}$ Bagian/SMF THT-KL Fakultas Kedokteran Universitas Sam Ratulangi/Rumah Sakit \\ Umum Prof. Dr. R. D. Kandou Manado, Indonesia \\ Email: novisolossa11@gmail.com
}

\begin{abstract}
Health problems such as throat disease can be caused by various factors either external or internal. This study was aimed to obtain a description of throat health status of students at Sekolah Dasar Negeri 11 (Public Elementary School) Manado. This was a descriptive and observational study with a cross sectional design. There were a total of 25 male and female students. The results showed that 25 students (100\%) had normal tonsil color; 24 students (96\%) had normal tonsil surface and one student (4\%) had pathological tonsil surface; 22 students (88\%) had normal tonsil size and three students (12\%) had pathological tonsil size. There were 25 students (100\%) who had normal results on examination of pharynx both mucosa and the back wall of pharynx. In conclusion, most students of SDN 11 Manado had normal throat health status. Keywords: throat health status; elementary students
\end{abstract}

\begin{abstract}
Abstrak: Masalah kesehatan seperti penyakit tenggorok dapat disebabkan oleh berbagai faktor baik eksternal maupun internal. Penelitian ini bertujuan untuk mendapatkan gambaran kesehatan tenggorok siswa Sekolah Dasar Negeri 11 Manado. Jenis penelitian ialah deskriptif observasional dengan desain potong lintang. Jumlah total keseluruhan subyek penelitian ialah 25 siswa. Hasil penelitian mendapatkan sebanyak 25 siswa (100\%) dengan warna tonsil normal; 24 siswa (96\%) dengan permukaan tonsil normal dan satu siswa (4\%) dengan permukaan tonsil patologik; 22 siswa (88\%) dengan ukuran tonsil normal dan 3 siswa (12\%) lainnya dengan ukuran tonsil patologik. Sebanyak 25 siswa (100\%) dengan hasil normal pada pemeriksaan faring baik mukosa maupun dinding belakang faring. Simpulan penelitian ini ialah sebagian besar siswa SDN 11 Manado memiliki gambaran kesehatan tenggorokan yang normal.
\end{abstract}

Kata kunci: kesehatan tenggorok; siswa Sekolah Dasar

\section{PENDAHULUAN}

Kesehatan sangat penting dan berperan penting dalam berbagai hal terutama dalam proses pertumbuhan dan perkembangan anak baik fisik maupun mental. Kurangnya pengetahuan dan pemahaman seseorang akan pentingnya kesehatan, merupakan salah satu pencetus timbulnya berbagai masalah kesehatan terutama pada tenggorok. Tenggorok (faring) merupakan separuh tabung muskulofasialis yang menghubungkan kavitas oris dan kavitas nasi serta berperan dalam proses pernapasan dan proses menelan. ${ }^{1}$

Faringitis adalah suatu peradangan pada dinding faring yang dapat disebabkan oleh berbagai hal terutama virus dan bakteri. Efek infeksi yang ditimbulkan bakteri grup A streptokokus $\beta$ sangat fatal seperti kerusakan jaringan yang hebat. Selain itu bakteri ini sering menyerang anak di bawah tiga tahun..$^{2-4}$

Tonsil merupakan suatu massa jaringan limfoid yang mengandung banyak limfosit dan berfungsi sebagai sistem kekebalan tubuh. $^{5}$ Tonsilitis merupakan salah satu 
gangguan tersering pada tenggorok setelah faringitis yang ditandai dengan adanya nyeri menelan akibat adanya kelainan atau peradangan. $^{2}$

Berdasarkan latar belakang yang telah dipaparkan maka penulis terdorong untuk mendapatkan gambaran kesehatan tenggorok pada siswa sekolah dasar, yang dalam penelitian ini ialah siswa SD Negeri 11 Manado.

\section{METODE PENELITIAN}

Penelitian ini dilaksanakan di SD Negeri 11 Manado. Sebagai populasi penelitian ialah siswa di SD Negeri 11 Manado sedangkan sampel penelitian ialah siswa yang bersedia dilakukan pemeriksaan THTKL. Variabel penelitian ialah hasil pemeriksaan tenggorok dan gangguan maupun kelainan pada tenggorok yang ditemukan pada saat pemeriksaan. Data yang terkumpul kemudian diolah dengan menggunakan Microsoft Word dan Microsoft Office Excel.

\section{HASIL PENELITIAN}

Penelitian ini dilakukan di SD Negeri

11 Manado. Pemeriksaan yang dilakukan meliputi pemeriksaan tonsil, mukosa faring, dan dinding belakang faring.

Subyek dalam penelitian ini berjumlah 25 siswa, didominasi oleh siswa laki-laki dengan jumlah 14 anak (56\%) sedangkan siswa perempuan sebanyak 11 anak (44\%).

Hasil terbanyak pada pemeriksaan tonsil ialah normal. Tabel 1 memperlihatkan bahwa pada pemeriksaan warna tonsil didapatkan sebanyak 25 siswa (100\%) tergolong normal. Tabel 2 memperlihatkan bahwa pada pemeriksaan pemukaan tonsil didapatkan sebanyak 24 siswa (96\%) tergolong normal. Tabel 3 memperlihatkan bahwa pada pemeriksaan ukuran tonsil didapatkan sebanyak 22 siswa (88\%) tergolong normal. Tabel 4 memperlihatkan bahwa pada pemeriksaan faring didapatkan 25 siswa (100\%) tergolong normal.

Tabel 1. Hasil pemeriksaan warna tonsil

\begin{tabular}{ccccc}
\hline Warna & \multicolumn{2}{c}{$\mathbf{N}$} & \multicolumn{2}{c}{$\%$} \\
Tonsil & Kiri & Kanan & Kiri & Kanan \\
\hline Normal & 25 & 25 & 100 & 100 \\
Hiperemis & 0 & 0 & 0 & 0 \\
Total & 25 & 25 & 100 & 100 \\
\hline
\end{tabular}

Tabel 2. Hasil pemeriksaan permukaan tonsil

\begin{tabular}{ccccc}
\hline $\begin{array}{c}\text { Permukaan } \\
\text { Tonsil }\end{array}$ & Kiri & Kanan & Kiri & Kanan \\
\hline Normal & 24 & 24 & 96 & 96 \\
Kripta lebar & 1 & 1 & 4 & 4 \\
Kasar & 0 & 0 & 0 & 0 \\
Detritus & 0 & 0 & 0 & 0 \\
Total & 25 & 25 & 100 & 100 \\
\hline
\end{tabular}

Tabel 3. Hasil pemeriksaan ukuran tonsil

\begin{tabular}{ccccc}
\hline $\begin{array}{c}\text { Ukuran } \\
\text { tonsil }\end{array}$ & Kiri & Kanan & Kiri & Kanan \\
\hline T0/T0 & 0 & 0 & 0 & 0 \\
T1/T1 & 22 & 22 & 88 & 88 \\
T2/T2 & 3 & 3 & 12 & 12 \\
T3/T3 & 0 & 0 & 0 & 0 \\
T4/T4 & 0 & 0 & 0 & 0 \\
Total & 25 & 25 & 100 & 100 \\
\hline
\end{tabular}


Tabel 4. Hasil pemeriksaan faring

\begin{tabular}{lcccc}
\hline \multicolumn{1}{c}{ Keadaan } & \multicolumn{2}{c}{ N } & \multicolumn{2}{c}{$\%$} \\
\hline Noring & Kiri & Kanan & Kiri & Kanan \\
Hiperemis & 25 & 25 & 100 & 100 \\
Granula hipertrofi & 0 & 0 & 0 & 0 \\
SDE & 0 & 0 & 0 & 0 \\
Total & 0 & 0 & 0 & 0 \\
\hline
\end{tabular}

\section{BAHASAN}

Hasil penelitian ini mendapatkan sebanyak 25 subyek penelitian dengan jenis kelamin terbanyak ialah laki-laki berjumlah 14 siswa dan perempuan berjumlah 11 siswa. Pemeriksaan dilakukan dengan mengamati warna, permukaan, serta ukuran tonsil-faring kanan dan kiri pada setiap subyek penelitian dan didapatkan yang terbanyak ialah hasil normal.

Pada pemeriksaan warna tonsil siswa SDN 11 Manado didapatkan sebanyak 25 siswa (100\%) memiliki warna tonsil yang normal. Hiperemis biasanya terjadi pada peradangan tonsil seperti tonsilitis yang dapat disebabkan oleh adanya infeksi virus maupun bakteri. ${ }^{6}$

Pada pemeriksaan permukaan tonsil siswa SDN 11 Manado didapatkan sebanyak 24 siswa (96\%) memiliki permukaan tonsil yang normal dan sebanyak satu siswa lakilaki (4\%) memiliki permukaan tonsil yang patologik dengan kripta melebar. Tonsil berada dalam kapsul dengan bagian terbesar terletak dalam fosa tonsil dengan perantaraan jaringan ikat jarang. Setiap folikel mempunyai kanal (saluran) yang bermuara di permukaan tonsil yang disebut kripta. Detritus merupakan hasil pembengkakan tonsil karena adanya radang pada folikel. Selain itu melebarnya kripta disebabkan oleh adanya proses radang akut yang mengakibatkan epitel mukosa serta jaringan limfoid terkikis diikuti dengan munculnya jaringan parut melalui proses regenerasi atau penyembuhan. ${ }^{4}$

Pada pemeriksaan ukuran tonsil siswa SDN 11 Manado didapatkan sebanyak 22 siswa (88\%) memiliki ukuran tonsil yang normal dengan klasifikasi T1/T1 dan sebanyak tiga siswa (12\%) memiliki ukuran tonsil abnormal dengan klasifikasi T2/T2 baik siswa laki-laki maupun perempuan. Tonsilitis merupakan gangguan utama yang sering menyerang tonsil dan secara umum terbagi atas tonsilitis akut dan kronik. Menurut data penelitian, tonsilitis akut sering menyerang anak usia 5-15 tahun. Prevalensi tonsilitis yang disebabkan oleh bakteri khususnya streptokokus ialah $15-30 \%$ pada anak dan 5-15\% pada orang dewasa. ${ }^{2,7}$

Pada pemeriksaan gambaran faring baik mukosa maupun dinding belakang faring didapatkan sebanyak 25 siswa (100\%) memiliki mukosa dan dinding belakang faring yang normal, tidak didapatkan hiperemis, granula, atau sulit dievaluasi. Granulasi pada mukosa faring disebabkan oleh adanya perubahan dinding posterior dan hiperplasia kelenjar limf di bawah mukosa faring. ${ }^{8}$

Hasil penelitian ini sejalan dengan penelitian yang telah dipaparkan sebelumnya mengenai gambaran kesehatan tenggorok pada anak. Masalah kesehatan terutama penyakit tenggorok seperti tonsilitis sekitar $80 \%$ lebih sering menyerang anak dibanding orang dewasa. ${ }^{6}$ Higiene mulut yang buruk serta pengobatan penyakit tenggorok yang tidak adekuat dapat merupakan faktor penyebab timbulnya masalah kesehatan tenggorok.

\section{SIMPULAN}

Siswa SD Negeri 11 Manado memiliki gambaran status kesehatan tenggorok yang baik.

Disarankan melakukan penelitian lanjut untuk mendeteksi masalah tenggorok secara 
lebih luas serta sebagai pencegahan dini.

\section{Konflik Kepentingan}

Penulis menyatakan tidak terdapat konflik kepentingan dalam studi ini.

\section{DAFTAR PUSTAKA}

1. George LA. Penyakit-penyakit nasofaring dan orofaring. In: Adams GL, Boeis LR, Highler PH, editors. Effendi H, Santoso RAK, penerjemah. Boeis Buku Ajar Penyakit THT (6th ed). Jakarta: EGC, 1997; p. 320.

2. Soepardi EA, Iskandar N, Bashiruddin J, Restuti RD. Buku Ajar Ilmu Kesehatan Telinga Hidung Tenggorokan Kepala dan Leher (6th ed). Jakarta: Balai Penerbit FKUI, 2007; p. 22, 212, 223.

3. Eibling DE. The oral cavity, pharynx and esophagus. In: Essential Otolaryngology Head and Neck Surgery (8th ed). New York: McGraw Hill Medical Publishing Division, 2003.
4. Herawati SJPB, Rukmini SS. Penyakit Telinga Hidung Tenggorok. In: Juwono L, editor. Buku Ajar Ilmu Penyakit Telinga Hidung Tenggorok untuk Mahasiswa Fakultas Kedokteran Gigi. Jakarta: EGC, 2003.

5. Hermani B, Fachrudin D, Syahrial MH. Tonsilektomi Pada Anak dan Dewasa. Jakarta: Health Technology Assessment (HTA) Indonesia, 2004.

6. Sidell D, Shapiro NL. Infect Disord Drug Targets. 2012;12(4):271-6. Available from: https://pubmed.ncbi.nlm.nih.gov/ 22338587/

7. Wald ER, Green MD, Schwartz B, Barbadora K. A streptococcal score card revisited. Pediatr Emerg Care. 1998;14(2):109-11.

8. Chan Y, Goddard JC, editors. Anatomy, physiology, and disorders of the oral cavity pharynx and esophagus. K. J. Lee's Essential Otolaryngology Head \& Neck Surgery (12th ed). New York: McGraw Hill Medical Publishing, 2019. 